\title{
Plasma Adiponectin and Resistin Levels in Type 2 Diabetic Obese Female Patients With and Without Hypertension and Retinopathy
}

\author{
Seham M. S. EL - Nakeeb*, Manal A.Lattif**, Ahmed M.Ragheb***, \\ Adel Balaha***, Baker M.A. Albow**** \\ Biochemistry Dept.* Internal Medicine Dept.** Faculty of Medicine for Girls AL-Azhar \\ University Clinical Pathology Dept.*** Faculty of Medicine AL-Azhar University, \\ Faculty of Medical Technology****,Mesalata- El- Margeb University.
}

\begin{abstract}
Background: In the past, adipose tissue was largely regarded as a depot for fuel storage in the form of triglyceride. However, adipose tissue is an active endocrine organ that secretes a variety of metabolically important substances including adipokines. The adipocyte is now known to secrete a variety of proteins such as tumour necrosis factor (TNF)- $\alpha$, adipsin, plasminogen activator inhibitor-1, leptin, resistin, and adiponectin. Adipose tissue regulates insulin sensitivity via the circulating adipocytokines, resistin and adiponectin. These factors affect insulin sensitivity and may represent a link between obesity, insulin resistance and type 2 diabetes (DM). The objective of this study was to compare the levels of resistin and adiponectin in type 2 diabetic obese female patients with and without hypertension and retinopathy.

Subjects and Methods: In this study the plasma adiponectin and resistin concentrations were investigated, in 20 control obese non-diabetic females and 40 obese female patients with type 2 diabetes mellitus. The diabetic females were divided into 2 groups. $\mathrm{G}_{\mathrm{I}}$ included 20 controlled uncomplicated diabetics \& $\mathrm{G}_{\mathrm{II}}$ included 20 diabetic patients with hypertension and retinopathy.

Results: The plasma concentration of adiponectin was significantly lower $(\mathrm{P}<0.01)$ in diabetic females in $G_{I} \& G_{\Pi}$ than non-diabetic control females. In diabetic patients with hypertension and retinopathy $\left(\mathrm{G}_{\mathrm{II}}\right)$ there was a significant decrease in plasma adiponectin levels $(P<0.01)$ as compared to their levels in diabetic females in $\mathrm{G}_{\mathrm{I}}$ and control females. Our results also show that there were non-significant changes in plasma resistin in diabetic patients in both groups $\mathrm{G}_{\mathrm{I}} \& \mathrm{G}_{\mathrm{II}}$ as compared to their levels in control group.

Conclusion: These results suggest that adiponectin may play a key role in pathophysiology of type 2 diabetes mellitus and its microangiopathy and macrovascular complications.
\end{abstract}

Key words: diabetes mellitus . obesity . adiponectin . resistin.

\section{Introduction}

Obesity is associated with an increased incidence of diabetes, hypertension, dyslipidaemia and coronary artery disease. Current management strategies of obesity include lifestyle interventions and pharmaco therapy (Filippatos et al., 2005) .Overweight (BMI $\left.\geq 25 \mathrm{~kg} / \mathrm{m}^{2}\right)$ and obesity (BMI $\geq 30 \mathrm{~kg} / \mathrm{m}^{2}$ ) are becoming increasingly prevalent in the industrialized world (James et al., 2001), not only in type 2 but also in type 1 diabetic patients (Libman et al., 2003 and Kibirige et al., 2003). Besides physical inactivity, intensive insulin therapy to obtain good metabolic control to reduce complications is associated with weight gain (Williams et al., 1999 and DCCT Research Group, 1993). The relationship between metabolic control and the development of chronic complications (retinopathy, neuropathy, and nephropathy) is a primary concern of clinicians. Factors involved in the development of vascular complications of diabetes include long diabetes duration, poor glycemic control, 
smoking, hypertension, and dyslipidemia, but the role of body weight/BMI is unclear (De Block et al., 2005).

Retinopathy may not only be related to glycemic control and diabetes duration but also to blood pressure and BMI for patients with type 2 diabetes, as was shown by the U.K. Prospective Diabetes Study (1998) and the Hoorn Study (van Leiden et al., 2002). However, information on the possible role of BMI on retinopathy in type 2 diabetes is scarce. Zhang et al. (2001) revisited data from the Diabetes Control and Complications Trial and observed that besides diabetes duration and metabolic control, BMI had a significant predictive value in developing retinopathy. In Sweden, Henricsson et al. (2003) observed that time to develop retinopathy was related to high $\mathrm{HbA}_{1} \mathrm{c}\left(\mathrm{A}_{1 \mathrm{C}}\right)$ and high BMI. Only one recent report suggested a role of BMI in neuropathy (Tesfaye et al., 2005). Adipocytokines, products from adipose tissue, have biological activities on the vascular system and may affect diabetic microangiopathy. Despite the abundance of studies on adipocytokines among type 2 diabetic patients or healthy individuals, there is only one study dealing with adiponectin and macrovascular complications in type 1 diabetes (Costacou et al., 2005). Because overweight is becoming increasingly prevalent and can be managed by lifestyle intervention (nutrition, exercise, and education), it seems appropriate to study the impact of overweight, which may reduce the impact of good metabolic control, on diabetes complications.

Adiponectin is an anti-diabetic and anti-atherogenic hormone that is exclusively secreted from fat cells. Serum adiponectin levels are reduced in obese patients and obese model mice, despite increased adipose tissue mass. Elucidation of the mechanism(s) by which plasma adiponectin levels are decreased in obese and diabetic patients would provide insight into the cause of obesity-induced diabetes and the development of therapeutic advances. In the Kamon et al., study, the regulation of adiponectin secretion was investigated using 3T3-L1 adipocytes and a diabetic-/obese-mouse model. A novel insulin sensitizer, IkappaB kinase beta (IKK beta) inhibitor, ameliorated insulin resistance and up-regulated plasma levels of adiponectin without producing a significant change in body weight in KKAy mice that were fed a high-fat diet. The IKKbeta inhibitor cancelled the TNF alpha-mediated down-regulation of adiponectin secretion and simultaneously up-regulated the phosphorylation of Akt in 3T3-L1 adipocytes. Using dominant-negative mutants of Akt or PKClambda (downstream effectors of phosphoinositide 3-kinase), insulin-stimulated Akt activity was found to be important in the regulation of adiponectin secretion by insulin in 3T3-L1 adipocytes. These observations suggest that "insulin-stimulated Akt activity in adipocytes" may play an important role in the regulation of adiponectin secretion (Kamon et al., 2004). Adiponectin deficiency leads to enhanced thrombus formation and platelet aggregation. The study of Kato et al. (2005) reveals a new role of adiponectin as an endogenous antithrombotic factor.

Resistin, an insulin inhibitor secreted by adipocytes, is associated with obesity and insulin resistance in mice. The role of resistin in human biology remains uncertain. Hasegawa et al., observed that resistin levels were increased significantly in patients with type 2 diabetes compared with non-diabetic subjects. However, there was no correlation in either patient groups between serum resistin levels and markers of insulin resistance, obesity or hyperlipidaemia. These results were in direct contrast to the data of leptin or adiponectin, both of which were closely related to these clinical markers of diabetes. Multivariate regression analysis on the combined data of the two groups demonstrated that the presence of diabetes and HDL cholesterol levels were significant predictors of serum resistin levels. No correlation was observed between Creactive protein and resistin adjusted for BMI. Taken together, these findings demonstrate that serum resistin levels are increased in patients with type 2 diabetes, but this increase is not linked to markers of insulin resistance or adiposity (Hasegawa et 
al., 2005). Further studies are necessary to elucidate the significance of serum resistin concentration in human pathophysiology. Our study aimed to assess the plasma adiponectin and resistin levels in type 2 diabetic obese female patients with and without hypertension and retinopathy.

\section{Subjects and Methods}

\section{Subjects}

Forty obese female patients with type

2 diabetes were selected for the present study from diabetic care unit in Al-Zahraa University Hospital. Participants with renal or liver dysfunction or active infection were excluded. They were divided into 2 groups. Group I $\left(\mathrm{G}_{\mathrm{I}}\right)$ included 20 diabetic females aged 48-59 years ,having diabetes for the past 5-10 years. All patients in $\mathrm{G}_{\mathrm{I}}$ had no history of diabetic ketoacidosis, nephropathy, cardiovascular disease and not suffering from any complications. Group II $\left(\mathrm{G}_{\Pi}\right)$ included 20 diabetic females with hypertension (blood pressure $\geq 130 / 90$ ) and retinopathy (retinopathy was examined by fundoscopy), aged 50-62 years, having diabetes for the past 9-12 years. Nine patients had a history of diabetic ketoacidosis and eight patients had a history of coronary artery disease. All patients with diabetes were treated with metformin and had not been taking other drug medication for the last one year before entering the study. The control subjects, 20 females, aged $47-60$ years were selected from among apparently healthy subjects. All participants gave their informed consent before the study began.

\section{Biochemical analysis}

Venous blood samples $(10 \mathrm{ml})$ were collected after an overnight fasting in tubes containing EDTA and were immediately centrifuged at $1500 \mathrm{rpm}$ for $15 \mathrm{~min}$ at $4^{\circ} \mathrm{C}$. Plasma samples were protected from light $\&$ frozen at $-80^{\circ} \mathrm{C}$ and stored until analysis. Plasma glucose was estimated by enzymatic colorimetric glucose oxidase method (Trinder, 1969). Glycohemoglobin $\mathrm{HbA}_{1 \mathrm{c}}$, was determined in whole blood by fast ionexchange resin separation method. The $\mathrm{HbA}_{1 \mathrm{c}} \%$ of total hemoglobin was determined by measuring the absorbance of $\mathrm{HbA}_{1 \mathrm{c}}$ and of the total hemoglobin fraction at 415 $\mathrm{nm}$ in comparison with a standard glycohemoglobin. Plasma adiponectin levels were measured using RIA kit for human adiponectin (Linco Research, Inc, St. Charles, Mo). The assay uses ${ }^{125}$ I-Labeled adiponectin and an antiadiponectin rabbit antiserum to determine adiponectin concentration by double-antibody/ polyet-hylene glycol technique. Plasma resistin levels were measured using human resistin ELISA kit (BioVendor Laboratory Medicine, Inc, Brno, Czech Republic) that uses rabbit polyclonal antihuman resistin antibody.

\section{Statistical analysis}

Data was entered into IBM compatible computer then analysis were done using SPSS $/ \mathrm{PC}^{+}$program for windows (Norusis, 1986). The following statistical procedures were performed (Saunders and Trapp,1990) arithmetic mean, standard deviation $( \pm \mathrm{SD})$, " $F$ " test, one way ANOVA to test for variations within groups $(\mathrm{P}-$ values less than 0.05 were considered significant) .

\section{Results}

Table (1) \& Fig (1) show that there was a significant decrease in plasma adiponectin $(\mathrm{P}<0.01)$ in diabetic females with and without hypertension and retinopathy, $\mathrm{G}_{\mathrm{I}} \& \mathrm{G}_{\mathrm{II}}$, as compared to their levels in control group. In diabetic patients with hypertension and retinopathy $\left(\mathrm{G}_{\mathrm{II}}\right)$ there was a significant decrease in plasma adiponectin levels $(\mathrm{P}<0.01)$ and significant increase in fasting plasma glucose levels $(\mathrm{P}<0.05)$ as compared to their levels in controlled uncomplicated diabetes patients $\left(\mathrm{G}_{\mathrm{I}}\right)$ and control groups. Table (1) \& Fig (2) also show that there were nonsignificant changes in plasma resistin levels in diabetic patients in all groups $\mathrm{G}_{\mathrm{I}} \& \mathrm{G}_{\mathrm{II}}$ as compared to their levels in control group. 
Table (1) :Clinical data and hormonal characteristics of Control \& diabetic patients with and without hypertension and retinopathy $\left(\mathbf{G}_{I} \& \mathbf{G}_{\text {III }}\right)$

\begin{tabular}{|c|c|c|c|c|}
\hline Parameters & Control group & $\begin{array}{c}\text { Controlled } \\
\text { uncomplicated } \\
\text { diabetes }\left(G_{\mathbf{I}}\right)\end{array}$ & $\begin{array}{l}\text { diabetes with } \\
\text { hypertension and } \\
\text { retinopathy } \\
\left(\mathbf{G}_{\mathrm{II}}\right)\end{array}$ & $\mathbf{P}<$ \\
\hline Age (years) & $51.4 \pm 7.3$ & $53.2 \pm 10$ & $52.4 \pm 9$ & N.S \\
\hline Weight $(\mathbf{k g})$ & $85.9 \pm 12.7$ & $85.6 \pm 14.7$ & $87.4 \pm 11.6$ & N.S \\
\hline BMI (kg/m2) & $30.7 \pm 7.5$ & $31.2 \pm 5.92$ & $32.9 \pm 6.73$ & N.S \\
\hline $\begin{array}{l}\text { Systemic Blood pressure } \\
\text { Systolic }(\mathbf{m m ~ H g}) \\
\text { Diastolic }(\mathbf{m m} \mathbf{H g})\end{array}$ & $\begin{array}{c}110.9 \pm 7.4 \\
65.1 \pm 5.7\end{array}$ & $\begin{array}{c}111.2 \pm 12.1 \\
67.4 \pm 8.1\end{array}$ & $\begin{array}{l}176 \pm 16.7^{*} \\
155.7 \pm 9.8^{*}\end{array}$ & $\begin{array}{l}0.01 \\
0.01\end{array}$ \\
\hline $\begin{array}{l}\text { The known duration of } \\
\text { diabetes (years) }\end{array}$ & --- & $7.8 \pm 2.01$ & $9.4 \pm 2.37$ & ---- \\
\hline Fasting plasma glucose (mM) & $4.37 \pm 1.5$ & $5.24 \pm 1.8$ & $6.3 \pm 1.2 *$ & 0.05 \\
\hline $\mathbf{H b} \mathbf{A}_{1 \mathbf{c}}$ & $5.4 \pm 0.1 \%$ & $5.8 \pm 0.3 \%$ & $8.5 \pm 0.7 \%$ & ---- \\
\hline Plasma adiponectin $(\mu \mathrm{g} / \mathrm{ml})$ & $8.3 \pm 3.2$ & $6.2 \pm 2.2^{*}$ & $4.09 \pm 2.31^{*}$ & 0.01 \\
\hline Plasma resistin (ng/ml) & $7.39 \pm 3.9$ & $7.95 \pm 2.9$ & $8.1 \pm 3.4$ & N.S \\
\hline
\end{tabular}

Data are expressed as the mean $\pm \mathrm{SD}$

N.S = non-significant

$*$ Significant $(\mathrm{P}<0.05)$

Systolic, diastolic blood pressure, plasma adiponectin \& fasting plasma glucose in diabetes with hypertension and retinopathy $\left(\mathrm{G}_{\mathrm{II}}\right)$ versus control $\& \mathrm{G}_{\mathrm{I}}$

Plasma adiponectin in controlled uncomplicated diabetes $\left(\mathrm{G}_{\mathrm{I}}\right)$ versus control \& $\mathrm{G}_{\text {II. }}$.

Fig(1) Plasma adiponectin levels in control, $G_{I} \& G_{I I}$

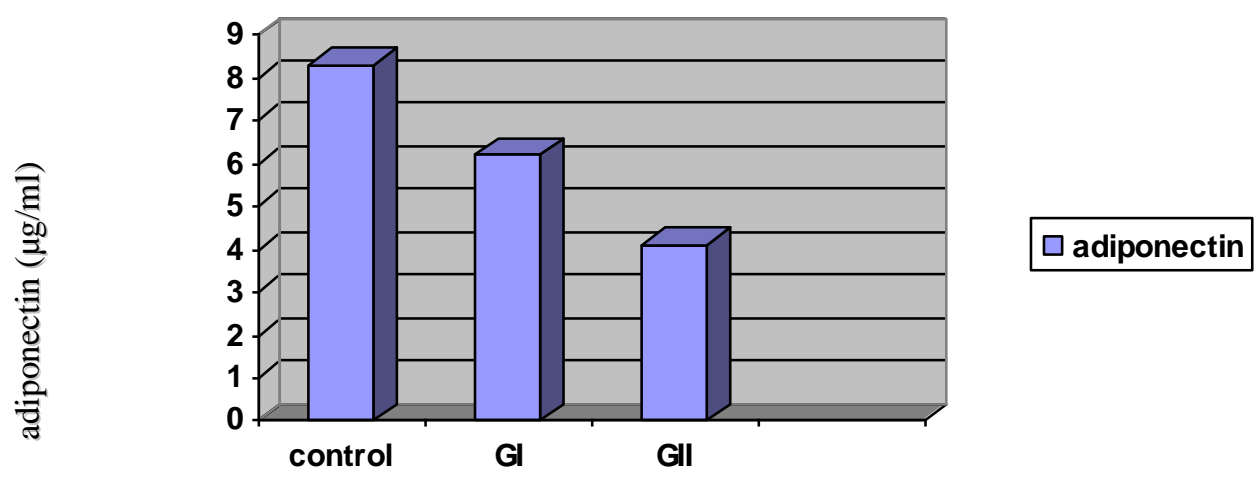


Fig(2) Plasma resistin levels in control, $\mathrm{G}_{\mathrm{I}} \& \mathrm{G}_{\mathrm{II}}$

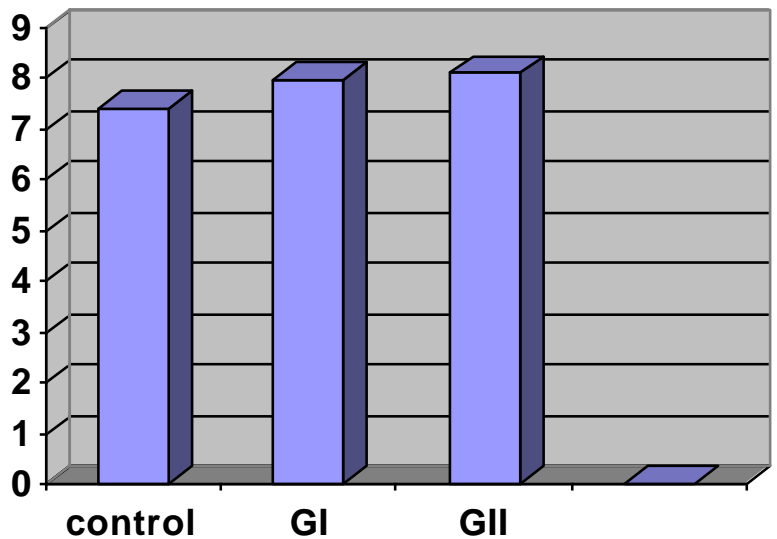

$\square$ resistin

$\mathrm{G}_{\mathrm{I}}=$ Controlled uncomplicated diabetes

$\mathrm{G}_{\mathrm{II}}=$ diabetes with hypertension and retinopathy.

\section{Discussion}

The raising prevalence of type-2 diabetes mellitus and obesity has been recognized as a major problem for public health, affecting both developed and developing countries. Impaired fasting plasma glucose has been previously associated with endothelial dysfunction, higher levels of inflammatory markers and increased risk of developing insulin resistance and cardiovascular events. Besides lifestyle changes, the blockade of the reninangiotensin system has been proposed as a useful alternative intervention to improve insulin resistance and decrease the number of new type- 2 diabetes cases (Lopez-Jaramillo et al., 2006).

Adiponectin and resistin are hormones that may represent a link between obesity and insulin resistance. Adiponectin, an adipocyte-derived factor, possesses antiatherogenic properties and is decreased in patients with insulin resistance (Weyer et al, 2001and Hotta et al., 2001). During the early phase of atherosclerosis, circulating monocytes attach to injured endothelial cells through adhesion molecules and invade the subintimal space (Ross, 1993 and Hotta et al., 2001). The monocytes transform into macrophages and secrete various cytokines and growth factors that promote smooth muscle cell proliferation.
Adiponectin inhibits the expression of adhesion molecules and prevents the attachment of monocytes in TNF- $\alpha-$ stimulated human aortic endothelial cells (Ouchi et al., 2000). This protein also dramatically suppresses the secretion of TNF- $\alpha$ from macrophages and foam cell formation (Ouchi et al., 2001). These data suggest that adiponectin works as an antiatherogenic molecule. Although its receptor has not been identified, adiponectin modulates $\mathrm{NF}_{\kappa} \mathrm{B}$ signaling, at least partly, through a cAMP-dependent pathway. The plasma adiponectin concentration is decreased in insulin-resistant states, such as obesity and type 2 diabetes (Arita et al., 1999). Kissebah et al. (2000) demonstrated two quantitative trait loci that influence the phenotypes of the insulin resistancemetabolic syndrome. One is located on chromosome $3 \mathrm{q} 27$, where the adiponectin gene is encoded (Takahashi et al., 2000). In light of these data, hypoadiponectinemia may play a role in the development of atherosclerotic vascular disease in patients with insulin resistance. The mechanisms that control the plasma adiponectin concentration have not been elucidated.

In the current study, we demonstrated a significant decrease in plasma adiponectin $(\mathrm{P}<0.01)$ in diabetic patients, controlled 
uncomplicated diabetes $\left(\mathrm{G}_{\mathrm{I}}\right)$ and diabetes with hypertension and retinopathy $\left(\mathrm{G}_{\mathrm{II}}\right)$ versus control. In diabetic patients with hypertension and retinopathy $\left(\mathrm{G}_{\mathrm{II}}\right)$ there were significant decreases in plasma adiponectin levels $(\mathrm{P}<0.01)$ and significant increases in fasting plasma glucose levels $(\mathrm{P}<0.05)$ as compared to their levels in controlled uncomplicated diabetic patients $\left(\mathrm{G}_{\mathrm{I}}\right)$ and control group. Our results also show that there were non-significant changes in plasma resistin levels in diabetic patients in both groups $\mathrm{G}_{\mathrm{I}} \&$ GII versus control group. These results are in agreement with those of Chen et al. (2005) who observed that plasma adiponectin was decrease in type 2 diabetic patients, while plasma resistin level did not differ between diabetic patients and control group. Baranova et al. (2006) observed that obese patients with insulin resistance have decreased serum adiponectin and increased serum resistin. Additionally, adiponectin gene expression is also decreased in the adipose tissue of these patients. Al-Harithy and Al-Ghamdi. (2005) also demonstrated that rsistin concentrations are elevated in patients with type 2 diabetes and are associated with obesity and insulin resistance. These data indicate that resistin might be involved in the development of diabetes in humans.

The mechanism responsible for the decreased adiponectin concentration in insulin resistance has been obscure. TNF- $\alpha$ is one of the candidate molecules responsible for causing insulin resistance (Hotamisligil et al., 1995).The expression and secretion of adiponectin from adipocytes were significantly reduced by TNF- $\alpha$ in a dose- and time-dependent manner via its promoter activity. The expression of adiponectin mRNA was reduced in the adipose tissue of insulinresistant obese humans and rodents, where TNF- $\alpha$ production was increased (Statnick et al., 2000). Therefore, increased TNF- $\alpha$ might be partially responsible for the decreased adiponectin production in obesity. Hojlund et al. (2006) observed that plasma adiponectin was significantly reduced in type 2 diabetic compared with obese and lean subjects. In lean and obese subjects, insulin significantly reduced plasma adiponectin, but this response was blunted in patients with type 2 diabetes.: these results indicate that plasma adiponectin may enhance insulin sensitivity by improving the capacity to switch from lipid to glucose oxidation and to store glucose as glycogen in response to insulin, and that low adiponectin may contribute to impaired insulin activation of glycogen synthase (GS) in skeletal muscle of patients with type 2 diabetes.

Clinical aspects of diabetes and obesity are somewhat different, even at similar levels of insulin resistance. Factors involved in pathophysiology, including different serum adiponectin levels and body fat distributions, are believed to be responsible for differences in clinical characteristics, even at similar levels of insulin resistance in both diseases(Kim et al., 2006). Plasma levels of adiponectin are lower in obese and insulin-resistant subjects compared with lean and insulin-sensitive ones. Thiazolidinediones increase plasma adiponectin levels in diabetic subjects, although the mechanism of this increased plasma adiponectin has not been well studied. Metformin did not cause any change in plasma or expression levels of adiponectin, but decreased plasma levels of resistin in impaired glucose tolerance subjects (Rasouli et al., 2006). In contrast to other adipokines, resistin is only weakly associated with body fat and is unlikely to be a major mediator of insulin resistance or the metabolic syndrome in humans (Utzschneider et al., 2005). In summary, higher adiponectin levels are associated with better glycemic control, more favorable lipid profile, and reduced inflammation in diabetic women (Mantzoros et al., 2005).

\section{Conclusion}

The current study showed that plasma adiponectin levels were significantly reduced in obese type 2 diabetic patients and is even lower in those patients with hypertension and retinopathy, while plasma resistin level did not differ between diabetic 
patients and control group. Our results suggest that adiponectin may play a key role in pathophysiology of type 2 diabetes mellitus and its microangiopathy and macro vascular complications.

\section{References}

1. Al-Harithy RN and Al-Ghamdi S.(2005) : Serum resistin, adiposity and insulin resistance in Saudi women with type 2 diabetes mellitus. Ann Saudi Med., 25 (4):283-7.

2. Arita Y, Kihara S, Ouchi N, et al. (1999): Paradoxical decrease of an adiposespecific protein, adiponectin, in obesity. Biochem Biophys Res Commun. , 257:7983.

3. Baranova A, Gowder SJ, Schlauch K, et al. (2006): Gene expression of leptin, resistin, and adiponectin in the white adipose tissue of obese patients with nonalcoholic Fatty liver disease and insulin resistance. Obes Surg., 16(9):1118-25.

4. Chen MP, Chung FM, Chang DM, et al. (2005): Elevated plasma level of Visfatin/pre-B cell colony-enhancing factor in patients with type 2 diabetes mellitus. J Clin. Endocrinol. Metab., 90(6):3665-72 .

5. Costacou T, Zgibor JC, Evans RW, Otvos J, et al. (2005) : The prospective association between adiponectin and coronary artery disease among individuals with type 1 diabetes: the Pittsburgh Epidemiology of Diabetes Complications Study. Diabetologia., 48: 41-48.

6. DCCT Research Group. (1993): The effect of intensive diabetes treatment on the development and progression of long-term complications in insulin-dependent diabetes mellitus: the Diabetes Control and Complications Trial. N Engl J Med., 329:977-986.

7. De Block CE, De Leeuw IH, and Van Gaal LF.(2005): Impact of overweight on chronic microvascular complications in type 1 diabetic patients. Diabetes Care, 28 (7):1649-1655.

8. Filippatos TD, Kiotsis DN, Liberopoulos EN, et al. (2005) A review of the metabolic effects of sibutramine. Curr Med Res Opin., 21(3): 457-68.

9. Hasegawa G, Ohta M, Ichida Y, et al. (2005) Increased serum resistin levels in patients with type 2 diabetes are not linked with markers of insulin resistance and adiposity. Acta Diabetol, 42(2):104-9.
10. Henricsson M, Nystrm L, Blohmé G, et al. (2003): The incidence of retinopathy 10 years after diagnosis in young adult people with diabetes: results from the nationwide population-based Diabetes Incidence Study in Sweden. Diabetes Care ., 26:349-354.

11. Hojlund K, Frystyk J, Levin $\mathrm{K}$, et al. (2006): Reduced plasma adiponectin concentrations may contribute to impaired insulin activation of glycogen synthase in skeletal muscle of patients with type 2 diabetes. Diabetologia., 49(6):1283-91.

12. Hotamisligil GS, Arner P, Caro JF , et al. (1995): Increased adipose tissue expression of tumor necrosis factor-alpha in human obesity and insulin resistance. J. Clin. Invest., 95:2409-2415.

13. Hotta K, Funahashi T, Bodkin NL, et al. (2001): Circulating concentrations of the adipocyte protein adiponectin are decreased in parallel with reduced insulin sensitivity during the progression to type 2 diabetes in rhesus monkeys. Diabetes, 50:1126-1133.

14. James PR, Leach R, Kalamara E, Shayeghi M.(2001): The worldwide obesity epidemic. Obes Res., 9:228S-233S.

15. Kamon J, Yamauchi T, Muto $\mathbf{S}$, et al .(2004) A novel IKKbeta inhibitor stimulates adiponectin levels and ameliorates obesity-linked insulin resistance. Biochem Biophys Res Commun., 8; 323(1):242-8.

16. Kato H, Kashiwagi H, Shiraga M. et al. Adiponectin Acts as an Endogenous Antithrombotic Factor. Arteriosclerosis, Thrombosis, and Vascular Biology, 26:2.

17. Kibirige $M$, Metcalf $B$, Renuka $R$, and Wilkin TJ:(2003): Testing the accelerator hypothesis: the relationship between body mass and age at diagnosis of type 1 diabetes. Diabetes Care. , 26:2865-2870.

18. Kim C, Park J, kang E, et al.(2006): Comparison of body fat composition and serum adiponectin levels in diabetic obesity and non-diabetic obesity.Obesity.,14 (7): 1164-71.

19. Kissebah AH, Sonnenberg GE, Myklebust J, et al.(2000): Quantitative trait loci on chromosomes 3 and 17 influence phenotypes of the metabolic syndrome. Proc. Natl. Acad. Sci. U S ., 97:14478-14483.

20. Libman IM, Pietropaolo M, Arslanian SA, LaPorte RE, Becker DJ.(2003): Changing prevalence of overweight children and adolescents at onset of insulin-treated diabetes. Diabetes Care , 26:2871-2875.

21. Lopez-Jaramillo P, Pradilla LP, Lahera V et al.(2006): A randomized, double 
blind, cross-over, placebo-controlled clinical trial to assess the effects of Candesartan on the insulin sensitivity on non diabetic, non hypertense subjects with dysglycemia and abdominal obesity. "ARAMIA". Trials., 7(1):28.

22. Mantzoros CS, Li T, Manson JE, Meigs JB, Hu FB.(2005): Circulating adiponectin levels are associated with better glycemic control, more favorable lipid profile, and reduced inflammation in women with type 2 diabetes. J. Clin. Endocrinol. Metab ., 90 (8): 4542-8.

23. Norusis MJ.(1986): SPSS/PC ${ }^{+}$program manual. Chicago PSS Incorporation.

24. Ouchi N, Kihara S, Arita Y, et al. (2001): Adipocyte-derived plasma protein, adiponectin, suppresses lipid accumulation and class A scavenger receptor expression in human monocyte-derived macrophages. Circulation ., 103:1057-1063.

25. Ouchi N, Kihara S, Arita Y, et al.(2000): Adiponectin, adipocyte-derived plasma protein, inhibits endothelial $\mathrm{NF}-\kappa \mathrm{B}$ signaling through cAMP-dependent pathway. Circulation., 102:1296-1301.

26. Rasouli N, Yao-Borengasser A, Miles LM, et al. (2006) Increased plasma adiponectin in response to pioglitazone does not result from increased gene expression. Am J. Physiol. Endocrinol. Metab., 290 (1): E42-E46.

27. Ross R. The pathogenesis of atherosclerosis. (1993): a perspective for the 1990s. Nature., 362:801-809.

28. Saunders BD and Trapp RG.(1990): Basic and clinical biostatistics. New Jersey: Prentice Hall International Inc., 104:163-164.

29. Statnick MA, Beavers LS, Conner LJ, et al.(2000) Decreased expression of apM-1 in omental and subcutaneous adipose tissue of humans with type 2 diabetes. Int $\mathrm{J}$ Exp Diabetes Res., 1:81-88.

30. Takahashi M, Arita Y, Yamagata $\mathrm{K}$, et al.(2000): Genomic structure and mutations in adipose-specific gene, adiponectin. Int $\mathrm{J}$. Obes, 24:861-868.

31. Tesfaye S, Chaturvedi N, Eaton SEM, et al (2005): Vascular risk factors and diabetic neuro-pathy. N Engl J Med, 352:341-350.

32. Trinder P.(1969): Determination of blood glucose using 4-aminophenazone. J. Clin Path., 22:246.

33. UK Prospective Diabetes Study (UKPDS) Group.(1998): Effect of intensive bloodglucose control with metformin on complications in overweight patients with type 2 diabetes (UKPDS34). Lancet., 352:854865.

34. UK Prospective Diabetes Study Group. (1998): Tight blood pressure control and risk of macrovascular and microvascular complic-ations in type 2 diabetes. UKPDS 38. BMJ, 317:703-713.

35. Utzschneider KM, Carr DB, Tong J, et al. (2005): Resistin is not associated with insulin sensitivity or the metabolic syndrome in humans. Diabetologia., 48 (11): 2330-3.

36. van Leiden HA, Dekker JM, Moll AC, et al. Blood pressure, lipids, and obesity are associated with retinopathy: the Hoorn study. Diabetes Care.,25:1320-1325.

37. Weyer C, Funahashi T, Tanaka S, et al. (2001): Hypoadiponectinemia in obesity and type 2 diabetes: close association with insulin resistance and hyperinsulinemia. J Clin Endocrinol Metab., 86:1930-1935.

38. Williams KV, Erbey JR, Becker D, Orchard TJ (1999): Improved glycemic control reduces the impact of weight gain on cardiovascular risk factors in type 1 diabetes: the Epidemiology of Diabetes Complications Study. Diabetes Care., 22: 1084-1091.

39. Zhang L, Krentowski G, Albert A, Lefebvre PJ.(2001) : Risk of developing retinopathy in Diabetes Control and Complications Trial type 1 diabetic patients with good or poor metabolic control. Diabetes Care. , 24 :1275-1279.

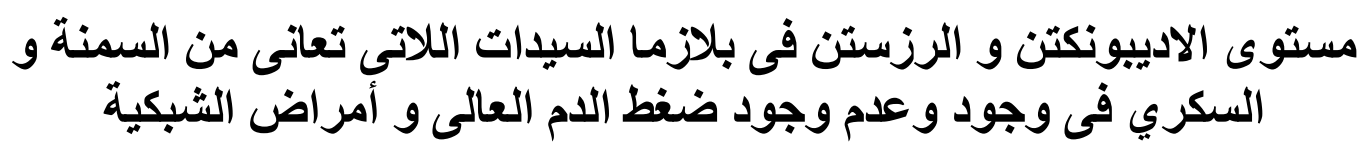




\section{سهام محمد سعيد النقيب*ـ منال عبد اللطيف **ـ أحمد محمد راغب **** عادل

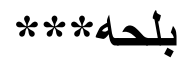

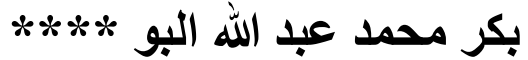

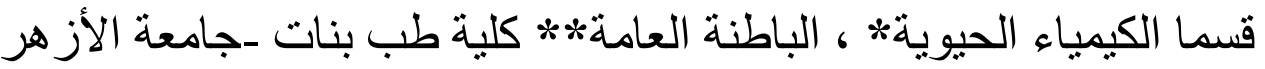

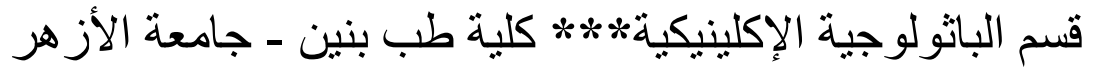
كلية التقنية الطبية***** * مسلاتة جامعة المرقب

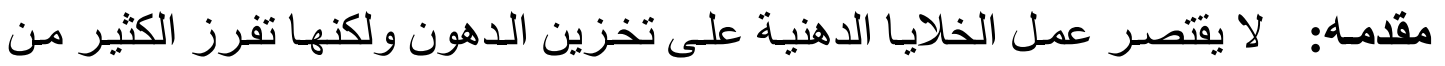

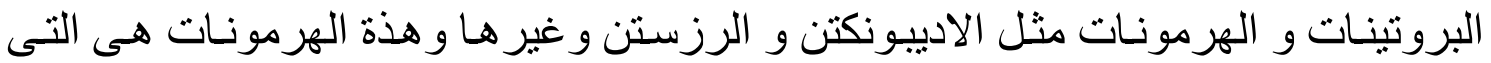

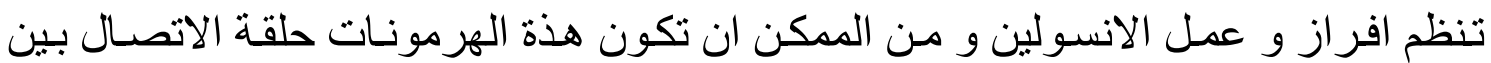

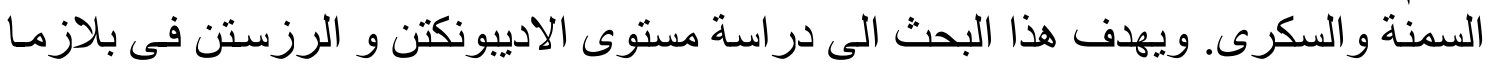

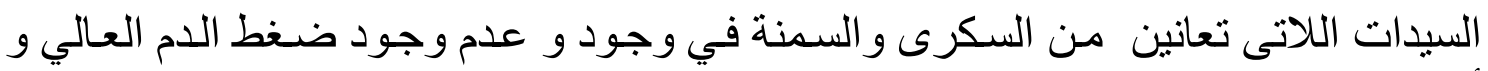

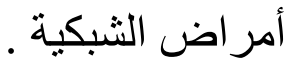

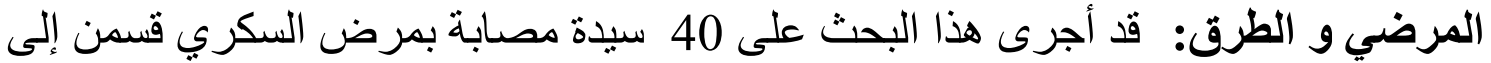

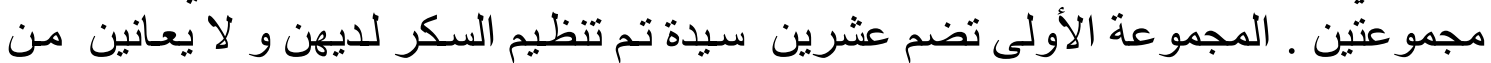

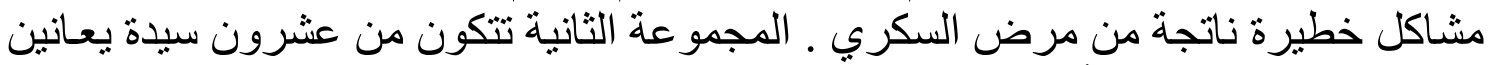

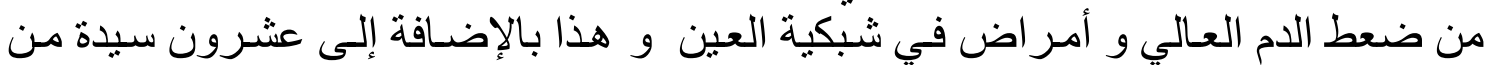

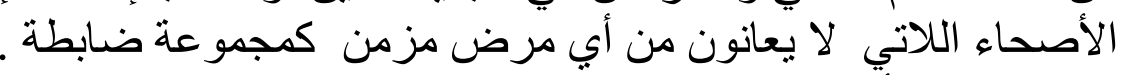

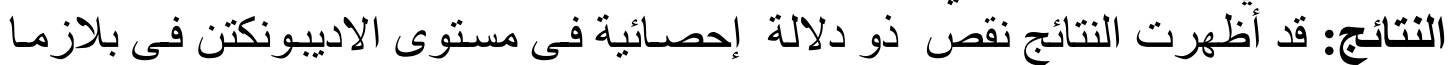

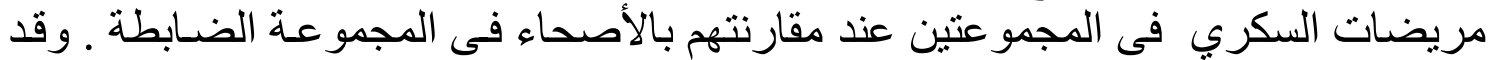

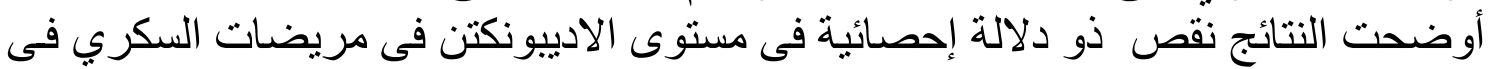

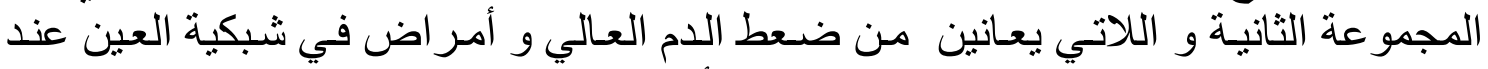

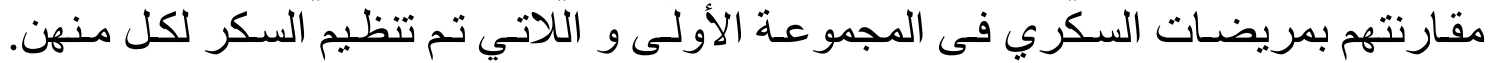

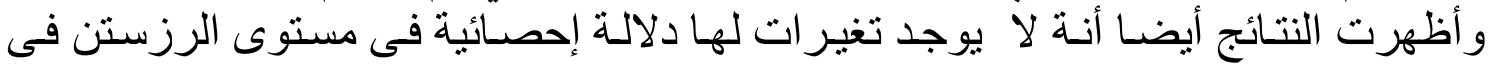

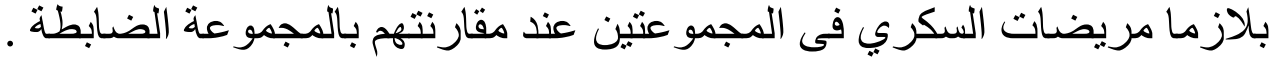

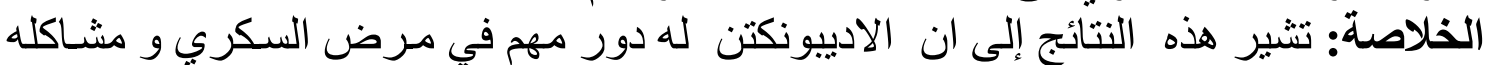
من زيادة في ضغطة تشنير الدم و أمر اض اضل الثبكية. 